\title{
Risk Management of Training Services in PT MMK
}

\author{
Bovi Mutiara Sofi ${ }^{1 *}$; Heti Mulyati²; Deni Achmad Soeboer ${ }^{3}$ \\ ${ }^{1}$ Business Management, Master Program Business Management, IPB Business School \\ Jln. Raya Pajajaran, Jawa Barat 16128, Indonesia \\ ${ }^{2}$ Department of Management, Faculty of Economics and Management, IPB University \\ Jln. Raya Dramaga, Jawa Barat 16680, Indonesia \\ ${ }^{3}$ Department of Fisheries Resources Utilization, Faculty of Fisheries and Marine Sciences, IPB University \\ Jln. Raya Dramaga, Jawa Barat 16680, Indonesia \\ 'mutiarabovi@gmail.com; ${ }^{2}$ heti@apps.ipb.ac.id; ${ }^{3}$ denisoeboer@gmail.com
}

Received: $10^{\text {th }}$ August 2020/ Revised: $14^{\text {th }}$ December 2020/ Accepted: $5^{\text {th }}$ February 2021

How to Cite: Sofi, B. M., Mulyati, H., \& Soeboer, D. A. (2021). Risk Management of Training Services in PT MMK. Binus Business Review, 12(3), 211-223. https://doi.org/10.21512/bbr.v12i3.6619

\begin{abstract}
One of the business training services that is rapidly grown is at the Occupational Health and Safety (Keselamatan dan Kesehatan Kerja (K3)) training services. PT MMK is a K3 training service company that has been developed since 2016. However, PT MMK faces some risks in its business activities. There are various problems and potential risks faced by PT MMK, so it needs a business risk management observation. The research aimed to identify and analyze the level of risk faced by PT MMK by applying a quantitative method. The primary and secondary data were used. Sampling was carried out by using non-probability techniques with purposive sampling through the expert judgment approach. There were eight respondents in the research. Meanwhile, the applied analytical methods were Cochran analysis and Godfrey risk map. The result shows that based on four divisions, PT MMK has 30 internal risks and 8 external risks. There are 4 low-level risks, 14 moderate-level risks, 19 high-level risks, and 1 extreme-level risk. Based on the highest risks, PT MMK should do detailed budgeting, so there is no over cost based on the previous training budget. Moreover, the company can also expand its market share to the other companies by offering its training.
\end{abstract}

Keywords: risk management, training services, service company

\section{INTRODUCTION}

Currently, Indonesia still faces problem of unemployment and low job skills. The total working population is 127,07 million people, and $5,12 \%$ are unemployed (BPS, 2018). This condition has an impact on decreasing per capita income, increasing social costs that the government must incur, and increasing state debt. Another problem is the lower quality of Indonesia's Human Resources (HR) than the average of other Southeast Asian countries (Anitasari \& Setiawan, 2017).

Training is one way to solve HR problems in Indonesia because it can add skills and increase job opportunities. According to Kahfi, Khurosani, and Suhendra (2017), training is a systematic process that can change a person's behavior by obtaining or learning specific attitudes, abilities, skills, knowledge, and practices related to a particular job. A person's skills and abilities will be more mature by training so that he or she can compete in the world of work (Ibrahim, Boerhannoeddin, \& Bakare, 2017). The government and the private sector hold various training. Hence, it encourages business opportunities for training services in various fields.

One of the growing training service businesses is in Occupational Health and Safety (Keselamatan dan Kesehatan Kerja (K3)) field. One of the factors driving the emergence of this business is the growing awareness of $\mathrm{K} 3$ in manufacturing companies. From 2016 to 2018, the licensing of the Occupational Safety and Health Service Company (Perusahaan Jasa Keselamatan dan Kesehatan Kerja (PJK3)) increased by $30 \%$ (Kementerian Ketenagakerjaan, 2018). The PJK3 has developed from 2016 to the present.

PT MMK has received a decree of direct 
appointment from the Indonesian Ministry of Labour to conduct training for K3 personnel. Currently, PT MMK has successfully conducted training in Jakarta, Bogor, Depok, Bandung, Semarang, Yogyakarta, Malang, Surabaya, Lampung, Palembang, and Medan. However, PT MMK faces some risks in its business activities. The risks are failure of training implementation due to the absence of participant quota, complaints about customer dissatisfaction, the safety of participants from undesirable things during the training, delays in training equipment, and damage to goods during the training. From 2016 to 2017, the company managed to meet the target. However, the training target was not achieved in 2018 while promotion costs were two times higher than the previous year. The goal to be made in 2018 was 105 pieces of training. Meanwhile, the training that could be carried out was 81 training. PT MMK training targets during 2016-2018 are presented in Figure 1.

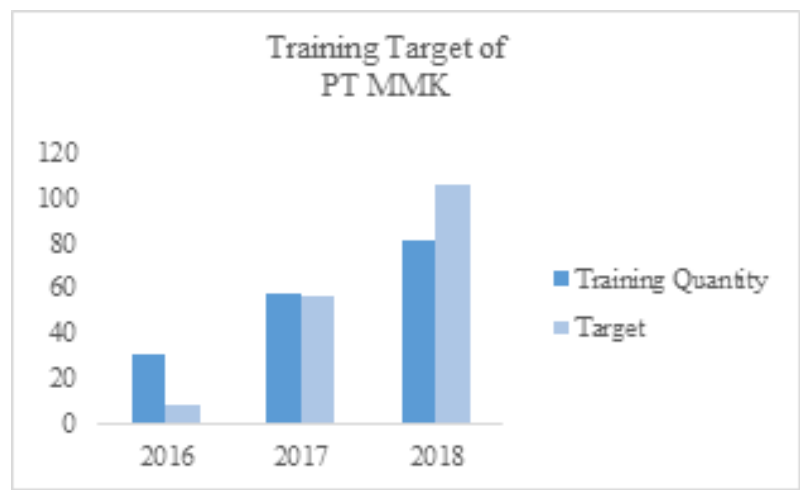

Figure 1 Target and Actual Training of PT MMK in 2016-2018

Unreachable targets with high promotional costs have an impact on the company from the financial and non-financial side. In 2018, PT MMK also experienced an increase in complaints. The number of claims submitted in 2018 reached $25 \%$. Meanwhile, in 2017, the complaints, such as facilities and materials that did not meet entry expectations, were only $11 \%$ of the total training participants (see Figure 2).

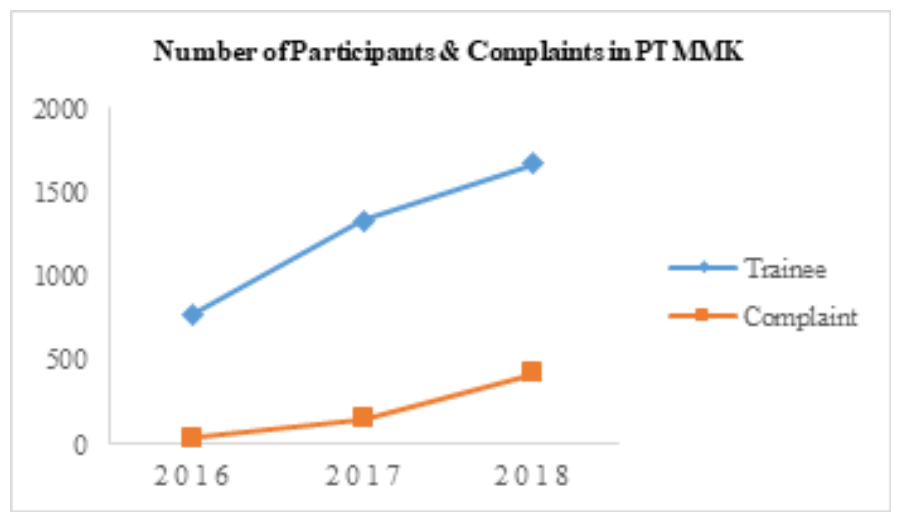

Figure 2 Number of Participants and Complaints in PT MMK in 2016-2018
The existence of various problems and potential risks faced by PT MMK needs a business risk management. Risk management is used to anticipate undesirable events in the future (McShane, 2018). According to Sulistyaningsih and Gunawan (2018), risk management is one of the crucial elements in running a company's business because the development and increasing complexity of the company increase the level of risk. Meanwhile, based on Agustinus, Nugroho, and Cahyono (2017), risk management analysis is an activity carried out at the executive leadership level, in the form of discovery and systematic analysis of losses that a company may face. It is due to risk and the most appropriate control method for handling losses associated with its profitability.

In the era of globalization, the devotion to the issues related to Enterprise Risk Management (ERM), sustainability reporting, and business performance grows in both research and practice. An organization with a rigorous ERM system is assumed to be better at making proper strategic and economic decisions (Shad, Lai, Fatt, Klemeš, \& Bokhari, 2019). Previous research concludes that the availability of a risk management toolkit enables the business entity to adequately respond to threats through the development and implementation of efficient behavioral strategies and implementation of appropriate crisis management measures to minimize risks in the face of uncertainty (Kiseleva, Karmanov, Korotkov, Kuznetsov, \& Gasparian, 2018). The efficiency of risk management depends on the precise information provided by various departments. Therefore, the particular issues that should be paid attention to are product quality control, financial activities control, HR control, pricing control, preliminary control, ongoing control, final control, strategic control, management control, and operational control.

Recent research conducted by Capocchi, Orlandini, Pierotti, Luzzi, and Minetti (2019) contributes to the knowledge related to riskmanagement policies in the healthcare sector. Based on the case study of Regione Lombardia, the research integrates the dimensions of organization and individuals with the cross-section of education and training in new risk-management systems. Meanwhile, another research identifies ten risk factors (Nasr, 2017). There are three internal risks and seven external risks in the tourism business. In addition, it has focused mainly on external risks. However, it shows that internal risks faced by tourism businesses in the travel and tour industry are among the most important risks.

Risk management plays a very important role in many businesses, including training provider businesses. The company will get more value in the company's business by implementing risk management. Companies that successfully implement effective risk management have a long-term competitive advantage and keep stakeholders from getting to their respective rights. A well-designed risk 
management system will ensure that all risky activities are carefully evaluated by responsible managers and employees (Soltanizadeh, Rasid, Golshan, \& Ismail, 2016). Based on that advantage, PT MMK needs to identify and analyze the level of risk to minimize losses.

Based on the description, the research aims to identify and analyze the level of risk and formulate the risk mitigation required by PT MMK. PT MMK does not consider the view of risk management adequately and does not take consequential decisions on a strategic level. As a newly established company, if the problem is ignored, it can decrease income, impacting the company. Therefore, the research intends to provide a practical approach to understand the risk management terminology in the training service company. Because of that, the research also discusses key concepts of risk management and its adoption approach in training service development organizations.

In this new framework, risk management has an essential role in realizing corporate governance. Through effective risk management, the company can minimize risks and impacts. Thus, the research also demonstrates the uncertain situation aroused in the management of PT MMK environment that causes uncertainty to many organizations with unpredictable costs. The research conceptually elaborates the possibility of irrepressible strategic mitigation methods to confront such costs.

\section{METHODS}

The research uses quantitative data to test the level of risk value in case studies in research. The research is conducted at PT MMK, locating in Depok, West Java, from December 2019 to February 2020. The data consist of primary and secondary data. Primary data are obtained by direct observation, interviews with respondents, and questionnaires. The selected respondents have competence, a role in determining policies, and the capacity to provide input at PT MMK. The respondents consist of eight people. The internal respondents include the director, operational manager, finance manager, $\mathrm{HRD}$, and a person in charge of the logistics division. Meanwhile, the external respondents are the Director of Supervision of Occupational Safety and Health Norms of the Ministry of Manpower of the Republic of Indonesia, the Head of the Sub-Directorate of Institutional and K3 Management Systems of the Indonesian Ministry of Manpower, and the Head of Association of Indonesian K3 Company Institutions (ALPK3I). The interviews with several experts and managers of PT MMK use deep interview techniques. Then, the questionnaires are given to respondents to measure the results of risk identification in terms of the amount of opportunity and the magnitude of the impact of each risk on the business of PT MMK. Moreover, secondary data are company documents, such as financial reports, marketing reports, operational reports of PT MMK during 2016-2019, and literature studies as research guidelines.

Then, sampling is carried out by using nonprobability sampling techniques with purposive sampling for respondents through expert judgment. Purposive or judgment sampling is a strategy in which particular persons or events are selected deliberately to provide relevant information that cannot be obtained from other choices. This sampling strength is low-cost, convenient, not time-consuming, and ideal for exploratory research design (Taherdoost, 2016). Similarly, according to Etikan, Musa, and Alkassim (2016), judgment sampling is a sampling procedure based on consideration of suitable characteristics relating to the sample members to answer the research objectives. This technique is a feasible sampling method to obtain the required information from particular sources, namely those who have the knowledge and know the sought facts. Table 1 shows the internal and external respondents.

Table 1 Internal and External Respondents

\begin{tabular}{|c|c|c|}
\hline Respondents & Position & Criteria \\
\hline Internal & $\begin{array}{l}\text { - } \text { Director } \\
\text { - Operational Manager } \\
\text { - Finance Manager } \\
\text { - HRD } \\
\text { - Responsible Logistics }\end{array}$ & $\begin{array}{l}\text { Having a role in determining } \\
\text { policies, as well as the capacity } \\
\text { to provide input. Having more } \\
\text { than one year work period at } \\
\text { PT MMK. }\end{array}$ \\
\hline External & $\begin{array}{l}\text { Director of K3 Norms Oversight at the } \\
\text { Indonesian Ministry of Labour } \\
\text { Head of Sub-Directorate for Institutional } \\
\text { and K3 Management Systems in Indonesian } \\
\text { Ministry of Labour } \\
\text { - Chairman of the Association of Indonesian K3 } \\
\text { Company Institutions (ALPK3I) }\end{array}$ & $\begin{array}{l}\text { Having the capacity and ability } \\
\text { to formulate policies }\end{array}$ \\
\hline
\end{tabular}


Cochran analysis is performed to determine the differences in responses of the samples to the same attributes in determining the importance of risk values using nominal numbers. The Cochran analysis uses a nominal scale. At this stage, respondents will be given a questionnaire that is filled in by providing the number zero or one for each available attribute (Sanny, Melita, \& Putri, 2019). A score of one is for the attributes that the respondents think are important. Meanwhile, a score of zero is for the attributes that the respondents feel are not important. The real level used in the Cochran analysis is 0,090 , with the Q count must be higher than the actual level.

Risk identification is carried out sequentially according to the work process listed in the Standard Operation Procedure (SOP) in the management work process of PT MMK. The result of risk identification is a list of potential risks found in each work process based on the organization's risk management objectives and risk appetite. The risk list is then measured using a Likert scale of one to five with the risk measurement method according to Godfrey (1996). Measurement is in terms of probability and impact on potential risk. The smallest impact and opportunity are one, and the largest is five. Then, the value of risk is obtained from the level of possibility and level of impact. The whole scales of probability and effect are presented in Tables 2 and 3.

Business risk management can help companies make the right mitigation decisions. The risk management process can be used to identify the risks faced by PT MMK. The identified risks are then analyzed based on the level of possibility and impact on the company. The decrease in the level of risk probability and impact affects the company's smooth running of business processes. The research framework is fully described in Figure 3.

Table 2 The Possibility Scale of Risk Occurrence

\begin{tabular}{lc}
\hline Frequency rate & Scale \\
\hline Frequent & 5 \\
Probable & 4 \\
Occasional & 3 \\
Remote & 2 \\
Improbable & 1 \\
\hline & (Source: Godfrey, 1996)
\end{tabular}

Table 3 The Impact Scale of Risk Occurrence

\begin{tabular}{lc}
\hline Frequency rate & Scale \\
\hline Catastrophic & 5 \\
Critical & 4 \\
Serious & 3 \\
Marginal & 2 \\
Negligible & 1 \\
\hline
\end{tabular}

(Source: Godfrey, 1996)

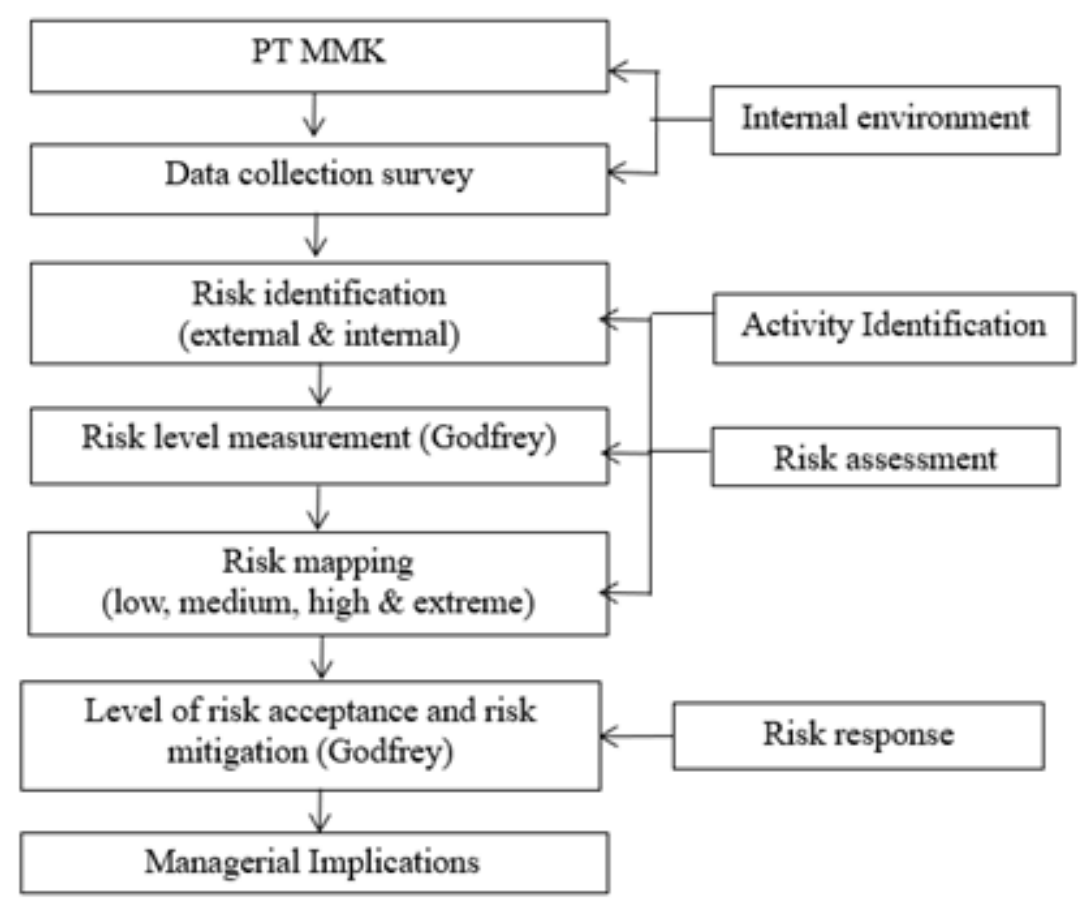

Figure 3 Research Framework 


\section{RESULTS AND DISCUSSIONS}

Risk management has an important role in realizing corporate governance through effective risk management so that companies can minimize risks and impacts (Kuncorowati, Achsani, \& Hafidhuddin, 2018). Risk identification activities are carried out by surveying the business activities of PT MMK. A survey is conducted to see the risks, which are then arranged in a check sheet. The check sheets used as an identification tool are grouped into internal risks and external risks. Internal risk is divided into several groups according to the divisions in PT MMK. Those divisions are the operational division, HR division, finance division, and logistic division.

According to IMA (2007), the risk category is divided into four groups: financial risk, strategic risk, hazard risk, and operational risk. Meanwhile, external risks are divided into several groups, namely government policies, association regulations, environment, customers, and competition. Based on Godfrey (1996), risk can come from 12 factors: politics, environment, planning, marketing, economic, finance, nature, project, technic, human, criminal, and safety.

Based on the identification results on the internal risks, there are 34 internal risks. Meanwhile, for external risk, there are 9 risks from all groups. The identification process uses samples consisting of the director, operational manager, financial manager, HRD, and logistics coordinator. In the next stage, questionnaires are given to respondents from 34 internal risks and 9 external ones. Then, they answer yes or no for each risk. In the first stage, the questionnaire is processed. The answer of yes is represented by one, while the answer of no is represented by zero. Identification of risks with a total value above $90 \%$ will be processed to the next stage. The results of the questionnaire in the first stage are shown in Table 4 (see Appendices). Later, the respondents are given the second questionnaire to determine each risk's level of possibility and impact.

PT MMK has four divisions consisting of logistics, HRD, finance, and operational divisions. In detail, there are seven business risks in the logistics division which can be seen in Table 5 (see Appendices). An example of risk in the logistics division is the delays in ordering training equipment. In this case, training equipment includes modules, block notes, pens, drinking bottles, identity straps, and field shirts. The order of training equipment at PT MMK is done by observing the implementation of training. Another logistics division risks at PT MMK are the dependence on one supplier. Dependence on one supplier is a risk because PT MMK already has a standard specification of production materials in each training equipment provided to participants. Weak internal company controls pose a risk of losing training support equipment.

In the finance division, there are five business risks, as seen in Table 6 (see Appendices). Checking the incoming money from training payments at PT MMK is done through manual checking by the finance division. The existence of a down payment system and the settlement of training fees at different times will make the transaction fee relatively high. Similarly, checking the manual payment system with a fairly high inflow by one staff member is deemed ineffective and becomes a factor in the delay in reporting the financial statements. Moreover, the types of training held by PT MMK are quite varied with different prices. The selling price error impacts the cost of the project's initial cost. It can cause losses to the company. Apart from this situation, the training carried out at one time causes the company's cash flow to be high.

Next, the high number of trainings held in various cities makes PT MMK lack HR to conduct it. This limited HR number also weakens the company's internal control because each employee has much work and still helps other divisions' work. Moreover, currently, PT MMK cannot increase HR, especially in conducting training. Hence, the company chooses to recruit temporary employees. The weakness of recruiting freelancers is that the service to participants is not optimal because providing the best service requires sufficient experience. As a result, mistakes often occur, such as inappropriate service from freelancers and inexperienced employees. Risk identification in the HR division can be seen in Table 7 (see Appendices).

Operational division risks come from the external environment, namely government policies, associations, customers, and competitors. For example, PT MMK collaborates with the Ministry of Manpower of the Republic of Indonesia to organize training and join the ALPK3I. Hence, operational risks can come from government policies, such as changes in regulations. Changes in regulations are the requirements for participating in the training.

Another problem in carrying out the training, PT MMK also depends on the number of training participants. Each training that will be held has a minimum number of participants that must be met. The minimum number is different in each training. For example, training in collaboration with the Ministry of Manpower of the Republic of Indonesia requires at least 20 participants. Meanwhile, the training organized by PT MMK needs a minimum of 15 participants. Then, the longer the training day is, the more the minimum number of participants must be fulfilled.

Failure to update marketing methods is an internal risk in marketing. The same marketing method over a long period is failed to renew the marketing method. Until now, PT MMK still relies on online marketing. Specific markets and very tight selling price competition make companies always have to innovate in marketing the training services to attract customers. From the obstacles faced, PT MMK does not know the effectiveness of the promotions carried out. When promoting on an account with a high number of followers with a pretty expensive cost, there is no guarantee that many participants will bring 
in many participants. Advertising costs have been spent relatively high, but the training still does not work. The risks in operational divisions can be seen in Table 8 (see Appendices).

Table 9 (see Appendices) presents the impact scale of internal and external risks in each division. It also shows the impact value of internal and external risks for each division. Scale 1 can be ignored by assuming a loss of Rp1.000.000,00, and scale 5 has a huge impact by assuming a loss of more than Rp10.000.000,00. PT MMK must pay attention to the risks that often occur to be evaluated, and the company can run effectively.

Based on 30 internal and 8 external risks, the operational division risk (dependent on participant quotas) is the highest risk faced by PT MMK, with a score of 24. This risk can be avoided by not holding training with little interest. PT MMK already has several types of training that are highly demanded and always running in every city. This alternative strategy can eliminate the risk of dependence on the number of participants. Apart from this, PT MMK can cooperate with similar training providers to organize training with few enthusiasts. Meanwhile, the risk that can be ignored is HR risk, which is the low employee discipline and organizational structure changes with a total value of 8 . However, this risk can be avoided by recruiting freelancers for each training event by providing a written SOP that the freelancer must obey to maintain the quality of service.

Then, the overall risk level calculation results are shown in Table 10 (see Appendices) and mapped in Figure 4. The level and risk map of PT MMK are calculated as a whole. The risk level is calculated using a geometric mean calculation. For example, the highest risk is over cost from the initial cost plan in the finance division. This risk can be avoided by carrying out detailed budgeting of each training held. Besides that, PT MMK must analyze the unexpected expenses that may occur from the previous training so that there is no over cost. According to Soltanizadeh et al. (2016), the main objective of risk management is to eliminate the possibility of low income earned by the organization and help organizations to optimize their capital and ownership structure. Another risk is competitive growth that continues to increase in the operational division. It is difficult to avoid. PT MMK can carry out other strategies, such as expanding market share. Until now, PT MMK's market share is students and fresh graduate students. The company can expand its market share to other companies. For example, PT MMK can offer more specific training types needed by other companies, such as Seiri, Seiton, Seiso, Seiketsu, \& Shitsuke (5S) training programs, service excellence, quality control, and quality assurance.

\section{Impact}

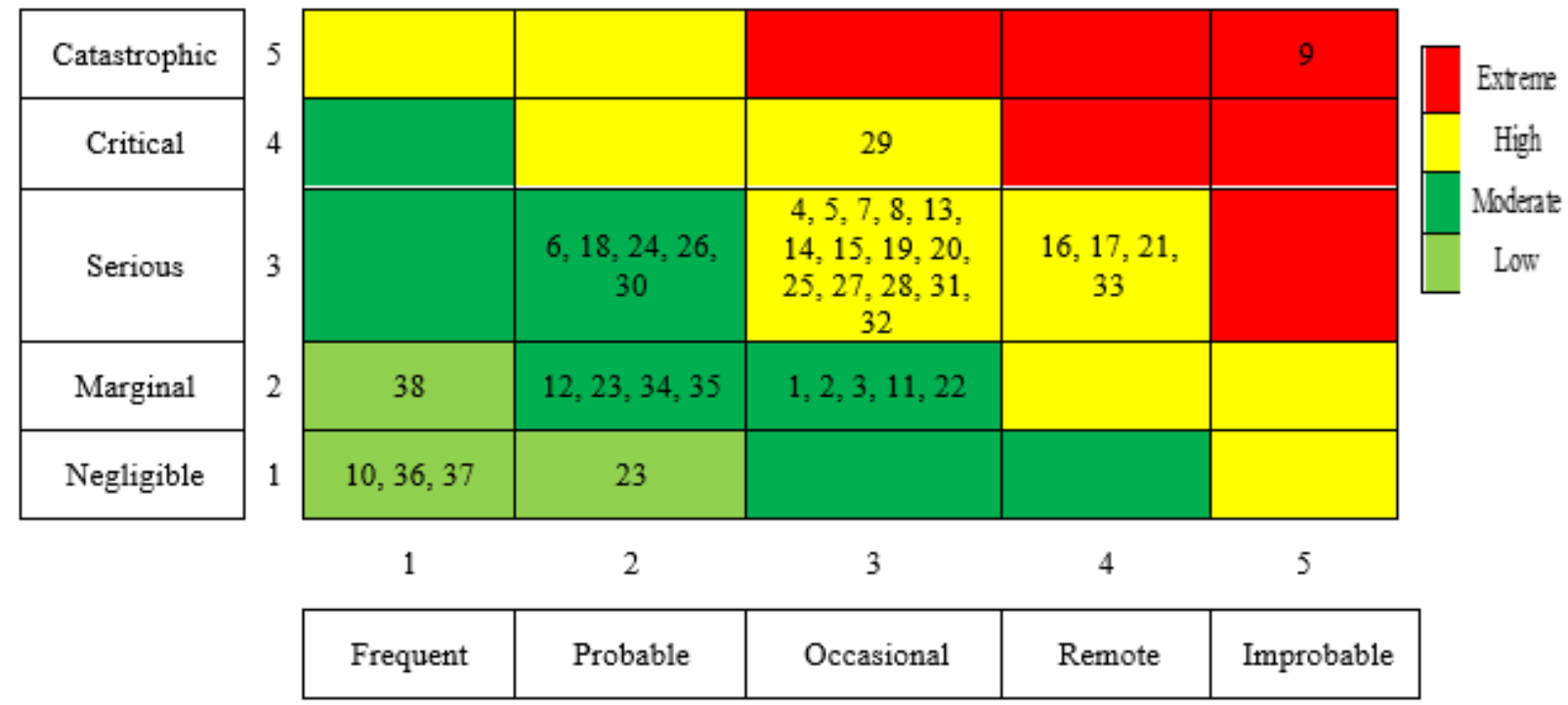

PROBABILITY

Figure 4 Risk Map at PT MMK 
The consequence for organizations due to poor risk management is the loss of competitiveness with consequent business weakening. The use of risk management can provide business confidence to the work team and the third parties involved. It supports the process of making decisions to minimize the risks by considering the organizational context. Organizations must have a system to incorporate risk assessment in all internal and external activities to minimize risks and remain sustainable. The risk management function has evolved to become a core area of business practice (Rebelo, Silva, \& Santos, 2017). Risk management results from new approaches and modified frameworks as new risks may occur due to the changing conditions (Tupa, Simota, \& Steiner, 2017).

The Godfrey risk map aims to analyze the level of risk faced by PT MMK. It is based on the level and risk map calculations from 38 risks contained in PT MMK. It has 4 low-level risks, 14 moderate-level risks, 19 high-level risks, and 1 extreme-level risk. The highest risk is in the operational division, which is the dependence on participant quotas. It is because each training has varying prices, so the participant limit must be met. If the minimum limit is not met, the training cannot run, which affects the company's targets and impacts the company's earnings. Companies must measure the level of marketing of each type of training managed so that companies can work together. Referring to Gazzola, Amelio, and Figus (2020), companies' risk management must be carried out consistently with a measurable methodology so that an audit can be carried out in the end.

Recommendations for PT MMK include collaborating with third parties to organize difficult training because of limited quotas or running programs with little interest. PT MMK is also advised to make service quality standards so that service quality is maintained when recruiting freelancers. Service quality has been discussed as an essential variable that creates a competitive advantage for a service provider. The conceptualization of service quality has accepted both tangible and easy measurable aspects of quality, such as defection rate, and intangible aspects, such as heterogeneity among service providers (Roy, Sreejesh, \& Bhatia, 2019). Simultaneously, the higher the service quality is, the newer and existing customers can be attracted and retained. It can even lure customers away from competitors. Therefore, service quality is crucial for attracting new customers and, more significantly, retaining existing ones (Tseng, 2016). Then, PT MMK should do detailed budgeting so that there is no over cost based on the previous training budget. The company can also expand its market share to other companies by offering the training.

\section{CONCLUSIONS}

Based on the research results at PT MMK, there are 38 risks, consisting of 30 internal risks and 8 external ones from all divisions. All of these risks have a total value of over $90 \%$. PT MMK should do detailed budgeting so that there is no over cost based on the previous training budget. The company can also expand its market by offering its training.

The research implication is that PT MMK can map training programs to be held every month or several times a year. Then, it should review the fluctuation of participants in the training every month. Hence, PT MMK can find out the productive months in issuing the training program. Moreover, it must also have service quality standards so that the quality of the provided training is maintained and reduces the risks that exist in the company.

However, the research also has a few limitations that may lead to the scope for future research. First, the research is conducted in PT MMK. Therefore, it will be interesting for future research to test the same model in a different service company. It will also add the generalizability of the findings. Second, the research only analyzes the business risk aspects as the outcomes of the service experience. A worthwhile future investigation can link the service experience to financial outcomes. Third, the research has not investigated the antecedents of service experience from the service receiver's view yet. Combining these in a more complex model can also lead to potential areas for further research.

\section{REFERENCES}

Agustinus, S., Nugroho, A., \& Cahyono, A. D. (2017). Analisis risiko teknologi informasi menggunakan ISO 31000 pada program HRMS. Jurnal RESTI (Rekayasa Sistem dan Teknologi Informasi), 1(3), 250-258.

Anitasari, L., \& Setiawan, R. (2017). Analisis pelatihan sumber daya manusia pada PT Restu Baru Indonesia. Agora, 5(1), 1-5.

BPS. (2018). Keadaan pekerja di Indonesia Februari 2018. Retrieved from https:// www.bps.go.id/publication/2018/06/04/ ffb632ad65f770914900ac29/keadaan-pekerja-diindonesia-februari-2018.html

Capocchi, A., Orlandini, P., Pierotti, M., Luzzi, L., \& Minetti, L. (2019). Risk management in the healthcare sector and the important role of education and training activities: The case of Regione Lombardia. International Journal of Business and Management, 14(1), 180-191.

Etikan, I., Musa, S. A., \& Alkassim, R. S. (2016). Comparison of convenience sampling and purposive sampling. American Journal of Theoretical and Applied Statistics, 5(1), 1-4.

Gazzola, P., Amelio, S., \& Figus, A. (2020). The double relationship between risk management and CSR in the Italian healthcare sector: The case of the Lombard "Health Protection Agencies" (ATS). In Contemporary Trends and Challenges in Finance (pp. 101-111). Springer.

Godfrey, P. (1996). Control of risk a guide to the systematic management of risk from contruction. CIRIA. 
Ibrahim, R., Boerhannoeddin, A., \& Bakare, K. K. (2017). The effect of soft skills and training methodology on employee performance. European Journal of Training and Development, 41(4), 388-406.

IMA. (2007). Enterprise risk management: Tools and techniques for effective implementation. Retrieved from https://erm.ncsu.edu/az/erm/i/chan/m-articles/ documents/IMAToolsTechniquesMay07.pdf.

Kahfi, H. S., Khurosani, A., \& Suhendra, I. (2017). Pengaruh pelatihan dan motivasi berprestasi terhadap kinerja pegawai dengan kompetensi sebagai variabel intervening (Studi empiris pada pegawai perusahaan daerah air minum Kabupaten Lebak). Jurnal Riset Bisnis dan Manajemen Tirtayasa, 1(1), 1-10.

Kementerian Ketenagakerjaan. (2018). Laporan kinerja 2018. Retrieved from https://ppid.kemnaker.go.id/ uploads/informasi_publik/723232139.pdf

Kiseleva, I. A., Karmanov, M. V., Korotkov, A. V, Kuznetsov, V. I., \& Gasparian, M. S. (2018). Risk management in business: Concept, types, evaluation criteria. Espacios, 39(27), 1-18.

Kuncorowati, D. E., Achsani, N. A., \& Hafidhuddin, D. (2018). Manajemen risiko wakaf di dompet dhuafa. Jurnal Aplikasi Bisnis dan Manajemen (JABM), 4(3), 441-441.

McShane, M. (2018). Enterprise risk management: History and a design science proposal. Journal of Risk Finance, 19(2), 137-153.

Nasr, N. E. S. (2017). Risk management in the light of travel agencies activity in Egypt. International Journal of Heritage, Tourism, and Hospitality, 10(2/2).

Rebelo, M. F., Silva, R., \& Santos, G. (2017). The integration of standardized management systems: Managing business risk. International Journal of Quality \& Reliability Management, 34(3), 395-405.
Roy, S., Sreejesh, S., \& Bhatia, S. (2019). Service quality versus service experience: An empirical examination of the consequential effects in B2B services. Industrial Marketing Management, 82, 52-69.

Sanny, L., Melita, S., \& Putri, S. (2019). Analysis of Indonesia's consumer preferences in choosing a co-working space. Journal of Southwest Jiaotong University, 54(4), 1-9.

Shad, M. K., Lai, F. W., Fatt, C. L., Klemeš, J. J., \& Bokhari, A. (2019). Integrating sustainability reporting into enterprise risk management and its relationship with business performance: A conceptual framework. Journal of Cleaner production, 208, 415-425.

Soltanizadeh, S., Rasid, S. Z. A., Golshan, N. M., \& Ismail, W. K. W. (2016). Business strategy, enterprise risk management and organizational performance. Management Research Review, 39(9), 1016-1033.

Sulistyaningsih, S., \& Gunawan, B. (2018). Analisis faktor-faktor yang memengaruhi risk management disclosure (Studi empiris pada perusahaan manufaktur yang terdaftar di Bursa Efek Indonesia tahun 2012-2014). Riset Akuntansi dan Keuangan Indonesia, 1(1), 1-11.

Taherdoost, H. (2016). Sampling methods in research methodology; How to choose a sampling technique for research. SSRN Electronic Journal, 5(2), 18-27.

Tseng, S. M. (2016). Knowledge management capability, customer relationship management, and service quality. Journal of Enterprise Information Management, 29(2), 202-221.

Tupa, J., Simota, J., \& Steiner, F. (2017). Aspects of risk management implementation for Industry 4.0. Procedia Manufacturing, 11, 1223-1230. 


\section{APPENDICES}

Table 4 The Results of Risk Identification

\begin{tabular}{|c|c|c|c|c|c|c|c|c|c|}
\hline \multirow{2}{*}{ No } & \multirow{2}{*}{ Risk Identification } & \multirow{2}{*}{$\mathbf{K}^{*}$} & \multicolumn{5}{|c|}{ Respondents } & \multirow{2}{*}{ Total } & \multirow{2}{*}{$\%$} \\
\hline & & & 1 & 2 & 3 & 4 & 5 & & \\
\hline 1 & Delay in ordering training equipment & $\mathrm{I}$ & 1 & 1 & 1 & 1 & 1 & 5 & $100 \%$ \\
\hline 2 & Late delivery of goods & I & 1 & 1 & 1 & 1 & 1 & 5 & $100 \%$ \\
\hline 3 & Dependence on one supplier & I & 1 & 1 & 1 & 1 & 1 & 5 & $100 \%$ \\
\hline 4 & Increase in training equipment price & I & 1 & 1 & 1 & 1 & 1 & 5 & $100 \%$ \\
\hline 5 & Unmatched stock taking & I & 1 & 1 & 1 & 1 & 1 & 5 & $100 \%$ \\
\hline 6 & Damage to training support equipment & I & 1 & 1 & 1 & 1 & 1 & 5 & $100 \%$ \\
\hline 7 & Loss of training support equipment & I & 1 & 1 & 1 & 1 & 1 & 5 & $100 \%$ \\
\hline 8 & HR limitations & I & 1 & 1 & 1 & 1 & 1 & 5 & $100 \%$ \\
\hline 9 & Human error & I & 1 & 1 & 1 & 1 & 1 & 5 & $100 \%$ \\
\hline 10 & Low employee discipline & I & 1 & 1 & 1 & 1 & 1 & 5 & $100 \%$ \\
\hline 11 & Lack of HR competence & I & 1 & 1 & 1 & 1 & 1 & 5 & $100 \%$ \\
\hline 12 & No reward and punishment system & I & 0 & 1 & 0 & 1 & 1 & 4 & $80 \%$ \\
\hline 13 & Changes in organizational structure & I & 1 & 1 & 1 & 1 & 1 & 5 & $100 \%$ \\
\hline 14 & Lack of competent teaching staff & I & 1 & 1 & 1 & 1 & 1 & 5 & $100 \%$ \\
\hline 15 & Lack of development services & I & 0 & 0 & 1 & 1 & 1 & 3 & $60 \%$ \\
\hline 16 & Delay in reporting time & I & 1 & 1 & 1 & 1 & 1 & 5 & $100 \%$ \\
\hline 17 & High cash flow & I & 1 & 1 & 1 & 1 & 1 & 5 & $100 \%$ \\
\hline 18 & Ineffective checking system for incoming money & I & 1 & 1 & 1 & 1 & 1 & 5 & $100 \%$ \\
\hline 19 & Decision error in selling price & I & 1 & 1 & 1 & 1 & 1 & 5 & $100 \%$ \\
\hline 20 & Over cost from the initial cost plan & I & 1 & 1 & 1 & 1 & 1 & 5 & $100 \%$ \\
\hline 21 & Owned capital limitations & I & 1 & 1 & 1 & 1 & 1 & 5 & $100 \%$ \\
\hline 22 & Less competitive fee structure & I & 0 & 0 & 0 & 1 & 1 & 2 & $40 \%$ \\
\hline 23 & Weak company's internal controls & I & 1 & 1 & 1 & 1 & 1 & 5 & $100 \%$ \\
\hline 24 & Dependence on participant quota & I & 1 & 1 & 1 & 1 & 1 & 5 & $100 \%$ \\
\hline 25 & Inconsistencies in training schedule and location & I & 1 & 1 & 1 & 1 & 1 & 5 & $100 \%$ \\
\hline 26 & No service quality standard & I & 1 & 1 & 1 & 1 & 1 & 5 & $100 \%$ \\
\hline 27 & No SOP & I & 1 & 1 & 1 & 1 & 1 & 5 & $100 \%$ \\
\hline 28 & Inadequate training facilities and equipment & I & 0 & 0 & 1 & 0 & 1 & 2 & $40 \%$ \\
\hline 29 & Increase in advertising costs & I & 1 & 1 & 1 & 1 & 1 & 5 & $100 \%$ \\
\hline 30 & Ineffective advertisement & I & 1 & 1 & 1 & 1 & 1 & 5 & $100 \%$ \\
\hline 31 & Failure to update marketing methods & I & 1 & 1 & 1 & 1 & 1 & 5 & $100 \%$ \\
\hline 32 & Reliance on marketing methods & I & 1 & 1 & 1 & 1 & 1 & 5 & $100 \%$ \\
\hline 33 & Limited market reach & I & 1 & 1 & 1 & 1 & 1 & 5 & $100 \%$ \\
\hline 34 & High selling price competition & I & 1 & 1 & 1 & 1 & 1 & 5 & $100 \%$ \\
\hline 35 & Regulatory changes & $\mathrm{E}$ & 1 & 1 & 1 & 1 & 1 & 5 & $100 \%$ \\
\hline 36 & Unfavorable political situation & $\mathrm{E}$ & 0 & 0 & 0 & 0 & 1 & 1 & $20 \%$ \\
\hline 37 & Non-competitive selling price & E & 1 & 1 & 1 & 1 & 1 & 5 & $100 \%$ \\
\hline 38 & High growth of competitors & $\mathrm{E}$ & 1 & 1 & 1 & 1 & 1 & 5 & $100 \%$ \\
\hline 39 & Increase in complaints & $\mathrm{E}$ & 1 & 1 & 1 & 1 & 1 & 5 & $100 \%$ \\
\hline 40 & Changes in customer preferences & $\mathrm{E}$ & 1 & 1 & 1 & 1 & 1 & 5 & $100 \%$ \\
\hline 41 & Flood & E & 1 & 1 & 1 & 1 & 1 & 5 & $100 \%$ \\
\hline 42 & Earthquake & $\mathrm{E}$ & 1 & 1 & 1 & 1 & 1 & 5 & $100 \%$ \\
\hline 43 & Fire & $\mathrm{E}$ & 1 & 1 & 1 & 1 & 1 & 5 & $100 \%$ \\
\hline
\end{tabular}

Note: $\mathrm{K}^{*}=$ Risk Group, $\mathrm{I}=$ internal, and $\mathrm{E}=$ external 
Table 5 The Risks of Logistics Division

\begin{tabular}{|c|c|c|c|c|c|c|c|c|c|c|}
\hline \multirow{2}{*}{ No } & \multirow{2}{*}{$\begin{array}{l}\text { Risk Identification } \\
\text { Delay in ordering training equipment }\end{array}$} & \multirow{2}{*}{$\frac{\mathbf{K}^{*}}{\mathrm{I}}$} & \multirow{2}{*}{$\begin{array}{l}\text { Division } \\
\text { Logistic }\end{array}$} & \multicolumn{5}{|c|}{ Respondents } & \multirow{2}{*}{ Total } & \multirow{2}{*}{$\frac{\text { Percentage }}{100 \%}$} \\
\hline & & & & 1 & 1 & 1 & 1 & 1 & & \\
\hline 2 & Late delivery of goods & I & Logistic & 1 & 1 & 1 & 1 & 1 & 5 & $100 \%$ \\
\hline 3 & Dependence on one supplier & I & Logistic & 1 & 1 & 1 & 1 & 1 & 5 & $100 \%$ \\
\hline 4 & Increase in the price of training equipment & I & Logistic & 1 & 1 & 1 & 1 & 1 & 5 & $100 \%$ \\
\hline 5 & Unmatched stock taking & I & Logistic & 1 & 1 & 1 & 1 & 1 & 5 & $100 \%$ \\
\hline 6 & Damage to training support equipment & I & Logistic & 1 & 1 & 1 & 1 & 1 & 5 & $100 \%$ \\
\hline 7 & Loss of training support equipment & I & Logistic & 1 & 1 & 1 & 1 & 1 & 5 & $100 \%$ \\
\hline
\end{tabular}

Note: $\mathrm{K}^{*}=$ Risk Group, $\mathrm{I}=$ internal, and $\mathrm{E}=$ =xternal

Table 6 The Risks of Finance Division

\begin{tabular}{|c|c|c|c|c|c|c|c|c|c|c|}
\hline \multirow{2}{*}{$\begin{array}{c}\text { No } \\
1\end{array}$} & \multirow{2}{*}{$\begin{array}{l}\text { Risk Identification } \\
\text { Delay in reporting time }\end{array}$} & \multirow{2}{*}{$\frac{\mathbf{K}^{*}}{\mathrm{I}}$} & \multirow{2}{*}{$\begin{array}{l}\text { Division } \\
\text { Finance }\end{array}$} & \multicolumn{5}{|c|}{ Respondents } & \multirow{2}{*}{$\frac{\text { Total }}{5}$} & \multirow{2}{*}{$\frac{\text { Percentage }}{100 \%}$} \\
\hline & & & & 1 & 1 & 1 & 1 & 1 & & \\
\hline 2 & High cash flow & I & Finance & 1 & 1 & 1 & 1 & 1 & 5 & $100 \%$ \\
\hline 3 & $\begin{array}{l}\text { Ineffective checking system for incoming } \\
\text { money }\end{array}$ & I & Finance & 1 & 1 & 1 & 1 & 1 & 5 & $100 \%$ \\
\hline 4 & Over cost from the initial cost plan & I & Finance & 1 & 1 & 1 & 1 & 1 & 5 & $100 \%$ \\
\hline 5 & Owned capital limitations & I & Finance & 1 & 1 & 1 & 1 & 1 & 5 & $100 \%$ \\
\hline
\end{tabular}

Note: $\mathrm{K}^{*}=$ Risk Group, $\mathrm{I}=$ internal, and $\mathrm{E}=$ =xternal

Table 7 The Risks of HRD Division

\begin{tabular}{|c|c|c|c|c|c|c|c|c|c|c|}
\hline \multirow{2}{*}{$\frac{\text { No }}{1}$} & \multirow{2}{*}{$\begin{array}{l}\text { Risk Identification } \\
\text { Human resource limitations }\end{array}$} & \multirow{2}{*}{$\frac{\mathbf{K}^{*}}{\mathrm{I}}$} & \multirow{2}{*}{$\frac{\text { Division }}{\text { HRD }}$} & \multicolumn{5}{|c|}{ Respondents } & \multirow{2}{*}{$\frac{\text { Total }}{5}$} & \multirow{2}{*}{$\frac{\text { Percentage }}{100 \%}$} \\
\hline & & & & 1 & 1 & 1 & 1 & 1 & & \\
\hline 2 & Human error & I & HRD & 1 & 1 & 1 & 1 & 1 & 5 & $100 \%$ \\
\hline 3 & Low employee discipline & $\mathrm{I}$ & HRD & 1 & 1 & 1 & 1 & 1 & 5 & $100 \%$ \\
\hline 4 & Lack of HR competence & I & HRD & 1 & 1 & 1 & 1 & 1 & 5 & $100 \%$ \\
\hline 5 & Changes in organizational structure & I & HRD & 1 & 1 & 1 & 1 & 1 & 5 & $100 \%$ \\
\hline
\end{tabular}

Note: $\mathrm{K}^{*}=$ Risk Group, $\mathrm{I}=$ internal, and $\mathrm{E}=$ external 
Table 8 The Risks of Operational Division

\begin{tabular}{|c|c|c|c|c|c|c|c|c|c|c|}
\hline \multirow{2}{*}{$\frac{\text { No }}{1}$} & \multirow{2}{*}{$\begin{array}{l}\text { Risk Identification } \\
\text { Weak company's internal controls }\end{array}$} & \multirow{2}{*}{$\frac{\mathbf{K}^{*}}{\mathrm{I}}$} & \multirow{2}{*}{$\frac{\text { Division }}{\text { Operational }}$} & \multicolumn{5}{|c|}{ Respondents } & \multirow{2}{*}{$\frac{\text { Total }}{5}$} & \multirow{2}{*}{$\frac{\text { Percentage }}{100 \%}$} \\
\hline & & & & 1 & 1 & 1 & 1 & 1 & & \\
\hline 2 & Dependence on participant quotas & I & Operational & 1 & 1 & 1 & 1 & 1 & 5 & $100 \%$ \\
\hline 3 & $\begin{array}{l}\text { Inconsistencies in training schedule and } \\
\text { location }\end{array}$ & I & Operational & 1 & 1 & 1 & 1 & 1 & 5 & $100 \%$ \\
\hline 4 & No service quality standard & I & Operational & 1 & 1 & 1 & 1 & 1 & 5 & $100 \%$ \\
\hline 5 & No SOP & I & Operational & 1 & 1 & 1 & 1 & 1 & 5 & $100 \%$ \\
\hline 6 & Increase in advertising costs & I & Operational & 1 & 1 & 1 & 1 & 1 & 5 & $100 \%$ \\
\hline 7 & Ineffective advertisement & I & Operational & 1 & 1 & 1 & 1 & 1 & 5 & $100 \%$ \\
\hline 8 & Failure to update marketing methods & I & Operational & 1 & 1 & 1 & 1 & 1 & 5 & $100 \%$ \\
\hline 9 & Reliance on marketing methods & I & Operational & 1 & 1 & 1 & 1 & 1 & 5 & $100 \%$ \\
\hline 10 & Limited market reach & $\mathrm{I}$ & Operational & 1 & 1 & 1 & 1 & 1 & 5 & $100 \%$ \\
\hline 11 & High selling price competition & I & Operational & 1 & 1 & 1 & 1 & 1 & 5 & $100 \%$ \\
\hline 12 & Lack of competent teaching staff & I & Operational & 1 & 1 & 1 & 1 & 1 & 5 & $100 \%$ \\
\hline 13 & Decision error in selling price & I & Operational & 1 & 1 & 1 & 1 & 1 & 5 & $100 \%$ \\
\hline 14 & Regulatory changes & $\mathrm{E}$ & Operational & 1 & 1 & 1 & 1 & 1 & 5 & $100 \%$ \\
\hline 15 & Non-competitive selling price & $\mathrm{E}$ & Operational & 1 & 1 & 1 & 1 & 1 & 5 & $100 \%$ \\
\hline 16 & High growth of competitors & $\mathrm{E}$ & Operational & 1 & 1 & 1 & 1 & 1 & 5 & $100 \%$ \\
\hline 17 & Increase in complaints & $\mathrm{E}$ & Operational & 1 & 1 & 1 & 1 & 1 & 5 & $100 \%$ \\
\hline 18 & Changes in customer preferences & $\mathrm{E}$ & Operational & 1 & 1 & 1 & 1 & 1 & 5 & $100 \%$ \\
\hline 19 & Flood & $\mathrm{E}$ & Operational & 1 & 1 & 1 & 1 & 1 & 5 & $100 \%$ \\
\hline 20 & Earthquake & $\mathrm{E}$ & Operational & 1 & 1 & 1 & 1 & 1 & 5 & $100 \%$ \\
\hline 21 & Fire & $\mathrm{E}$ & Operational & 1 & 1 & 1 & 1 & 1 & 5 & $100 \%$ \\
\hline
\end{tabular}

Note: $\mathrm{K}^{*}=$ Risk Group, $\mathrm{I}=$ internal, and $\mathrm{E}=$ =xternal 
Table 9 The Risk Impact Scale

\begin{tabular}{|c|c|c|c|c|c|c|c|c|c|}
\hline \multirow{2}{*}{ No } & \multirow{2}{*}{ Risks } & \multirow{2}{*}{$\mathbf{K}^{*}$} & \multirow{2}{*}{ Div. } & \multicolumn{5}{|c|}{ Impact } & \multirow{2}{*}{ Tota } \\
\hline & & & & 1 & 2 & 3 & 4 & 5 & \\
\hline 1 & Delay in ordering training equipment & I & $\mathrm{L}$ & 1 & 2 & 3 & 5 & 1 & 12 \\
\hline 2 & Delay in delivery of goods & $\mathrm{I}$ & $\mathrm{L}$ & 1 & 2 & 5 & 4 & 1 & 13 \\
\hline 3 & Dependence on one supplier & $\mathrm{I}$ & $\mathrm{L}$ & 2 & 2 & 3 & 5 & 1 & 13 \\
\hline 4 & Increase in the price of training equipment & $\mathrm{I}$ & $\mathrm{L}$ & 3 & 3 & 5 & 4 & 1 & 16 \\
\hline 5 & Unmatched stock taking & I & $\mathrm{L}$ & 3 & 4 & 3 & 4 & 2 & 16 \\
\hline 6 & Damage to training support equipment & $\mathrm{I}$ & $\mathrm{L}$ & 3 & 4 & 2 & 4 & 3 & 16 \\
\hline 7 & Loss of training support equipment & $\mathrm{I}$ & $\mathrm{L}$ & 1 & 4 & 5 & 2 & 4 & 16 \\
\hline 8 & Human resource limitations & I & $\mathrm{H}$ & 4 & 3 & 3 & 5 & 3 & 18 \\
\hline 9 & Human error & $\mathrm{I}$ & $\mathrm{H}$ & 2 & 3 & 4 & 4 & 2 & 15 \\
\hline 10 & Low employee discipline & $\mathrm{I}$ & $\mathrm{H}$ & 1 & 3 & 2 & 1 & 1 & 8 \\
\hline 11 & Lack of HR competence & I & $\mathrm{H}$ & 2 & 2 & 3 & 3 & 1 & 11 \\
\hline 12 & Changes in organizational structure & $\mathrm{I}$ & $\mathrm{H}$ & 1 & 3 & 2 & 1 & 1 & 8 \\
\hline 13 & Delay in reporting time & I & $\mathrm{F}$ & 1 & 2 & 3 & 3 & 5 & 14 \\
\hline 14 & High cash flow & $\mathrm{I}$ & $\mathrm{F}$ & 3 & 4 & 4 & 2 & 3 & 15 \\
\hline 15 & Ineffective checking system for incoming money & $\mathrm{I}$ & $\mathrm{F}$ & 2 & 5 & 3 & 3 & 4 & 17 \\
\hline 16 & Decision error in selling price & I & $\mathrm{F}$ & 3 & 3 & 3 & 4 & 3 & 16 \\
\hline 17 & Over cost from the initial cost plan & I & $\mathrm{F}$ & 3 & 3 & 4 & 5 & 5 & 20 \\
\hline 18 & Owned capital limitations & I & $\mathrm{F}$ & 5 & 4 & 1 & 5 & 2 & 17 \\
\hline 19 & Weak company's internal controls & $\mathrm{I}$ & $\mathrm{O}$ & 2 & 4 & 5 & 5 & 1 & 17 \\
\hline 20 & Dependence on participant quotas & I & $\mathrm{O}$ & 5 & 5 & 5 & 5 & 4 & 24 \\
\hline 21 & Inconsistencies in training schedule and location & I & $\mathrm{O}$ & 3 & 2 & 4 & 5 & 2 & 16 \\
\hline 22 & No service quality standard & I & $\mathrm{O}$ & 1 & 2 & 3 & 3 & 1 & 10 \\
\hline 23 & No SOP & I & $\mathrm{O}$ & 1 & 3 & 2 & 2 & 1 & 9 \\
\hline 24 & Increase in advertising costs & I & $\mathrm{O}$ & 3 & 2 & 4 & 3 & 1 & 13 \\
\hline 25 & Ineffective advertisement & $\mathrm{I}$ & $\mathrm{O}$ & 2 & 5 & 5 & 3 & 2 & 17 \\
\hline 26 & Failure to update marketing methods & $\mathrm{I}$ & $\mathrm{O}$ & 2 & 5 & 3 & 2 & 2 & 14 \\
\hline 27 & Reliance on marketing methods & $\mathrm{I}$ & $\mathrm{O}$ & 4 & 4 & 2 & 3 & 4 & 17 \\
\hline 28 & Limited market coverage & $\mathrm{I}$ & $\mathrm{O}$ & 5 & 4 & 3 & 4 & 1 & 17 \\
\hline 29 & High selling price competition & I & $\mathrm{O}$ & 5 & 5 & 2 & 5 & 1 & 18 \\
\hline 30 & Lack of competent teaching staff & I & $\mathrm{O}$ & 3 & 3 & 5 & 3 & 1 & 15 \\
\hline 31 & Regulatory changes & $\mathrm{E}$ & $\mathrm{O}$ & 4 & 2 & 3 & 5 & 1 & 16 \\
\hline 32 & Non-competitive selling price & $\mathrm{E}$ & $\mathrm{O}$ & 5 & 4 & 3 & 5 & 1 & 18 \\
\hline 33 & High growth of competitors & $\mathrm{E}$ & $\mathrm{O}$ & 3 & 2 & 4 & 3 & 2 & 14 \\
\hline 34 & Increase in complaints & $\mathrm{E}$ & $\mathrm{O}$ & 3 & 3 & 2 & 1 & 2 & 11 \\
\hline 35 & Changes in customer preferences & $\mathrm{E}$ & $\mathrm{O}$ & 2 & 2 & 3 & 2 & 2 & 11 \\
\hline 36 & Flood & $\mathrm{E}$ & $\mathrm{O}$ & 3 & 4 & 1 & 1 & 2 & 11 \\
\hline 37 & Earthquake & $\mathrm{E}$ & $\mathrm{O}$ & 3 & 4 & 1 & 1 & 2 & 11 \\
\hline 38 & Fire & $\mathrm{E}$ & $\mathrm{O}$ & 3 & 4 & 1 & 1 & 3 & 12 \\
\hline
\end{tabular}

Note: $\mathrm{K}^{*}=$ Risk group, $\mathrm{I}=$ Internal, $\mathrm{E}=$ External, $\mathrm{L}=$ Logistic, $\mathrm{O}=$ Operational, $\mathrm{H}=\mathrm{HRD}, \mathrm{K}=$ Finance 
Table 10 The Average of Respondents' Answers to the Possibility (P) and Impact (I) of Risk (R)

\begin{tabular}{|c|c|c|c|c|c|c|c|}
\hline No & Risk & $\mathbf{K}^{*}$ & Div. & $\mathbf{P}$ & $\mathbf{I}$ & $\mathbf{R}$ & Level \\
\hline 1 & Delay in ordering training equipment & I & $\mathrm{L}$ & 3,1 & 2 & 6,1 & Moderate \\
\hline 2 & Delay in delivery of goods & I & $\mathrm{L}$ & 2,6 & 2,1 & 5,4 & Moderate \\
\hline 3 & Dependence on one supplier & I & $\mathrm{L}$ & 2,8 & 2,3 & 6,3 & Moderate \\
\hline 4 & Increase in the price of training equipment & I & $\mathrm{L}$ & 2,5 & 2,8 & 7 & High \\
\hline 5 & Unmatched stock taking & I & $\mathrm{L}$ & 2,9 & 3,1 & 9,1 & High \\
\hline 6 & Damage to training support equipment & I & $\mathrm{L}$ & 1,9 & 3,1 & 6 & Moderate \\
\hline 7 & Loss of training support equipment & I & $\mathrm{L}$ & 2,5 & 2,7 & 6,9 & High \\
\hline 8 & Human resource limitations & I & $\mathrm{H}$ & 3 & 3,5 & 10,5 & High \\
\hline 9 & Human error & I & $\mathrm{H}$ & 3,4 & 2,9 & 9,6 & High \\
\hline 10 & Low employee discipline & I & $\mathrm{H}$ & 1,3 & 1,4 & 1,9 & Low \\
\hline 11 & Lack of HR competence & I & $\mathrm{H}$ & 2 & 2 & 4,2 & Moderate \\
\hline 12 & Changes in organizational structure & I & $\mathrm{H}$ & 1,8 & 1,4 & 2,5 & Moderate \\
\hline 13 & Delay in reporting time & I & $\mathrm{F}$ & 2,9 & 2,5 & 7,2 & High \\
\hline 14 & High cash flow & I & $\mathrm{F}$ & 3,4 & 3,1 & 10,7 & High \\
\hline 15 & Ineffective checking system for incoming money & I & $\mathrm{F}$ & 2,6 & 3,2 & 11,6 & High \\
\hline 16 & Decision error in selling price & I & $\mathrm{F}$ & 3 & 3,2 & 9,5 & High \\
\hline 17 & Over cost from the initial cost plan & I & $\mathrm{F}$ & 3,3 & 3,9 & 12,8 & High \\
\hline 18 & Owned capital limitations & I & $\mathrm{F}$ & 2,4 & 2,9 & 6,8 & Moderate \\
\hline 19 & Weak company's internal controls & I & $\mathrm{O}$ & 3 & 2,9 & 8,6 & High \\
\hline 20 & Dependence on participant quotas & I & $\mathrm{O}$ & 5 & 4,8 & 24 & Extreme \\
\hline 21 & Inconsistencies in training schedule and location & I & $\mathrm{O}$ & 3,7 & 3 & 11,1 & High \\
\hline 22 & No service quality standard & I & $\mathrm{O}$ & 3,2 & 1,8 & 5,8 & Moderate \\
\hline 23 & No SOP & I & $\mathrm{O}$ & 1,6 & 1,6 & 2,7 & Moderate \\
\hline 24 & Increase in advertising costs & I & $\mathrm{O}$ & 2,4 & 2,4 & 5,7 & Moderate \\
\hline 25 & Ineffective advertisement & I & $\mathrm{O}$ & 2,9 & 3,1 & 9,2 & High \\
\hline 26 & Failure to update marketing methods & I & $\mathrm{O}$ & 2,2 & 2,6 & 5,6 & Moderate \\
\hline 27 & Reliance on marketing methods & I & $\mathrm{O}$ & 3,8 & 3,3 & 12,3 & High \\
\hline 28 & Limited market coverage & I & $\mathrm{O}$ & 3,9 & 3 & 11,8 & High \\
\hline 29 & High selling price competition & I & $\mathrm{O}$ & 4 & 3 & 12 & High \\
\hline 30 & Lack of competent teaching staff & I & $\mathrm{O}$ & 2,3 & 2,7 & 6 & Moderate \\
\hline 31 & Regulatory changes & $\mathrm{E}$ & $\mathrm{O}$ & 3,1 & 2,6 & 8,2 & High \\
\hline 32 & Non-competitive selling price & E & $\mathrm{O}$ & 3 & 3,1 & 9,4 & High \\
\hline 33 & High growth of competitors & $\mathrm{E}$ & $\mathrm{O}$ & 3,7 & 2,7 & 10,1 & High \\
\hline 34 & Increase in complaints & $\mathrm{E}$ & $\mathrm{O}$ & 1,7 & 2 & 3,6 & Moderate \\
\hline 35 & Changes in customer preferences & $\mathrm{E}$ & $\mathrm{O}$ & 2,3 & 2,2 & 5,1 & Moderate \\
\hline 36 & Flood & $\mathrm{E}$ & $\mathrm{O}$ & 1,1 & 1,2 & 2,2 & Low \\
\hline 37 & Earthquake & $\mathrm{E}$ & $\mathrm{O}$ & 1,1 & $1 ., 2$ & 2,2 & Low \\
\hline 38 & Fire & E & $\mathrm{O}$ & 1,2 & 2 & 2,6 & Low \\
\hline
\end{tabular}

Note: $\mathrm{K}^{*}=$ Risk group, $\mathrm{I}=$ Internal, $\mathrm{E}=$ External, $\mathrm{L}=$ Logistic, $\mathrm{O}=$ Operational, $\mathrm{H}=\mathrm{HRD}, \mathrm{K}=\mathrm{Finance}$ 